<総 説 $>$

(受理 : 平成 26 年 5 月 2 日)

\title{
ガスバリアフィルムの評価と国際標準化 Testing Methods of Gas Barrier Films and Its International Standardization
}

\author{
永井 一 清* \\ Kazukiyo NAGAI
}

\section{1.はじめに}

有機エレクトロ・ルミネッセンス（EL）や太陽電池, 電子ペーパー，液晶等の電子デパイス製品には接着剤が使 用されている。本報は被着材となるプラスチック基板に関 する総説である。

電子デバイス製品の基板には，ガラス材料が使用されて きた。ここにプラスチック材料を使用すればフレキシブル 化が実現する。プラスチック材料は軽量化や耐衝撃性等で あガラス材料よりあ優れるため，必ずしむフレキシブル性 を求める用途だけに使用されているわけではない。現在の 基板はガラスであるが，それにプラスチックが加われば応 用分野の展開，ひいては市場の拡大につながるものと考え られる。

しかしながら，ガラス基板と比較してプラスチック基板 は, 耐熱性や酸素ガスおよび水蒸気のバリア性等において 劣っている。特にデバイスとしての寿命を考えると，プラ スチック基板へのバリア性の付与は極めて重要な課題であ る。ガラスは完全なガスバリア性を有しているが，プラス チックはガスを透過させてしまう。つまりプラスチック材 料におけるバリア性は, “低透過性”之言い換えることが できる。実際, 国際標準化機構（International Organization for Standardization: ISO) 等ではバリア性を示す物 性值として遮断した割合を表すバリア度ではなく透過度 (transmission rate) が使用されている。透過度が小さい あのをバリア性が高いと表現している。

プラスチックのバリア性の研究は, 1950 年代から食品 包装フィルム分野で行われており，私たちの暮らしの中に

\footnotetext{
$*$ 明治大学理工学部応用化学科

神奈川県川崎市多摩区東三田 1-1-1 于 214-8571

Department of Applied Chemistry, Meiji University

1-1-1 Higashi-mita, Tama-ku, Kawasaki 214-8571, Japan
}

満ち溢れるほどにこの市場は成熟してきている。しかし， 有機 EL や太陽電池で必要とされるバリア性は, 食品包装 分野で求められるバリア性よりも数桁厳しいとされており, 現在この条件を満たすプラスチック素材は存在しない。そ こでプラスチックフィルムの上に数十ナノメートルの無機 薄膜層を蒸着させ，さらにバウムクーヘン状に多層構造を とることによりハイバリア性フレキシブル基板を形成させ ている。この様な高いバリア性開発は, 従来の食品や医薬 品, 電子機器包装等の包装分野の新しい展開の可能性を広 げる相乗効果ももたらしている。

図 1 に各産業で必要とされている常温常圧付近での酸素 と水蒸気のバリア性の概念図を示す。例えば，水蒸気透過 度 WVTR (Water vapor transmission rate) をみてみる と, 食品包装用途では 1-100 $\mathrm{g} \mathrm{m}^{-2} \mathrm{day}^{-1}$, 有機薄膜太陽 電池のバックシート用途で $10^{-2}-10^{-3} \mathrm{~g} \mathrm{~m}^{-2} \mathrm{day}^{-1}$, 有機 EL 基板用途で $10^{-5}-10^{-6} \mathrm{~g} \mathrm{~m}^{-2} \mathrm{day}^{-1}$ が一つの目安となっ ている。分析評価時間として考えると, 食品包装用途の透 過性の速さを 10 秒台で走る 100 メートル走とすると有機 EL 基板用途は 2 日かけて行われる箱根駅伝位の時間のか かり方の違いがある。そこで大きな問題が存在する。太陽 電池や有機 EL 用途で求められる透過度の測定評価はバリ

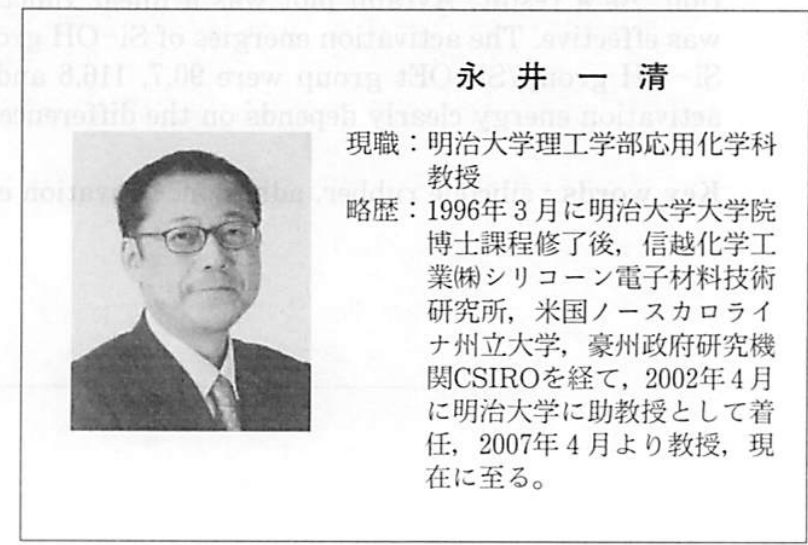




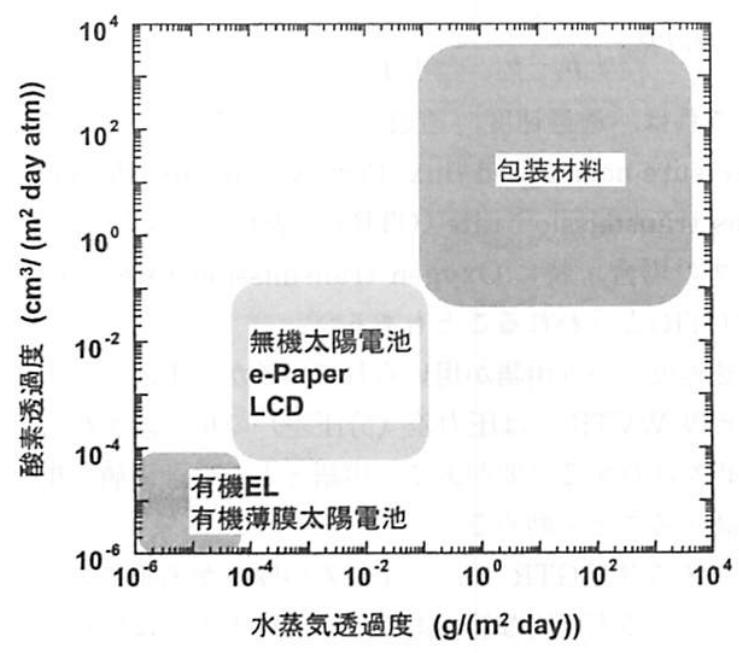

図 1 産業界で要求される酸素と水蒸気のバリア性の概念

ア度が高いために，まだ確立されていないということであ る。食品包装用途のバリア度の測定評価技術は 1980 年代 には確立され，1990年代にかけて国際標準化む達成され ている。太陽電池や有機 EL 用途で求められるバリア度は, ここ 10 年程の間に求められるようになってきたあのであ り, 各担当者がそれぞれの工夫をこらして測定評価を行っ ているのが実情である。

後者の分析評価法は今後の電子デバイス材料開発のカギ を握るむのである。経済産業省は 2010 年に国際標準化政 府戦略分野の一つとして, “有機 EL・有機薄膜太陽電池 の封止材の性能評価”を挙げ，2011年度から筆者が統括 者として同戦略的国際標準化推進事業を実施している。

そして 2011 年 9 月 25 日〜9 月 30 日にマレーシアで開 催された第 60 回 ISO/TC61-Plastics 国際会議にて, 我 が国から同評価方法の予備提案がなされ承認された。現在, 新規 ISO 規格が審議されている。

本報では，ガスバリアフィルムの評価と国際標準化につ いて概説する。

\section{2. ガスバリア性とは何か}

ガスバリア性とは何か, まずは使用する人の間での共通 の理解と認識が必要であるはずであるが, ガスバリア性の 評価用語之評価値の単位は, 産業界により異なる場合が多 い。同分野が化学工学産業, 纎維産業, プラスチック産業, フィルム産業, コンバーティング産業, 分析機器産業等で 独立して成長してきたためと思われる。そのため評価用語 の定義と評価值の単位の統一がなされていない現実がある。 英語表記は IUPAC で用語が推奖されているが, 国際ジャー ナルの論文を読んでみると表記が徹底されていない現状が ある。また, 英語表記と日本語表記が必ずしも対応してい るわけではなく, 一つの英語表記を意味する日本語表記が 複数存在する場合むある。従って, 文献を読む際には用語
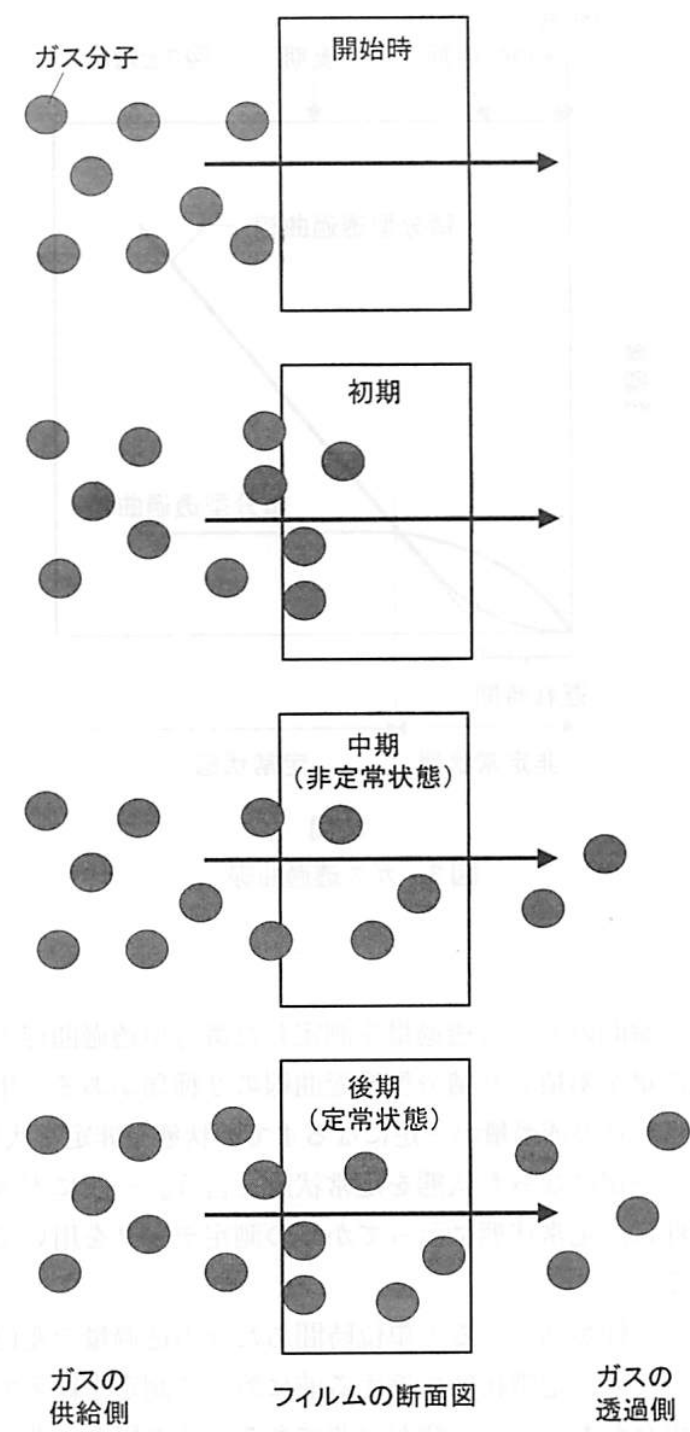

図 2 フィルムを通してのガス透過の概念図

の意味に注意する必要がある。その対応策の一例は, 用語 ととあに評価值の単位を確認することである。

一般にガスバリア性の測定は，フィルム状で行われる。 フィルムのガスバリア性を評価するためには，フィルムを 通してガスがどの程度透過または遮断されるのかを測定す ればよい。実際には，透過した割合で評価されている。

ガスの透過の測定法では，フィルムを挟んでガスの供給 側と透過側は共に気相である。図 2 に示すようにフィルム を通してガスが移動するためには，何かしらの透過の駆動 力が必要である。測定ではその駆動力として, ガスの圧力 差か濃度差を用いている。濃度差む, 言い換えればガス中 の目的とする成分の分圧差である。

測定開始時には，フィルム内部に測定するガスは存在し ない。そのためフィルムの片面からガスを導入した後に， その反対面から出てくるガスの透過量が一定になるまでに 時間を要する。この間に要する時間を遅れ時間と言う。図 3 に，ガス導入時をゼロ点としたガスの透過曲線の例を示 


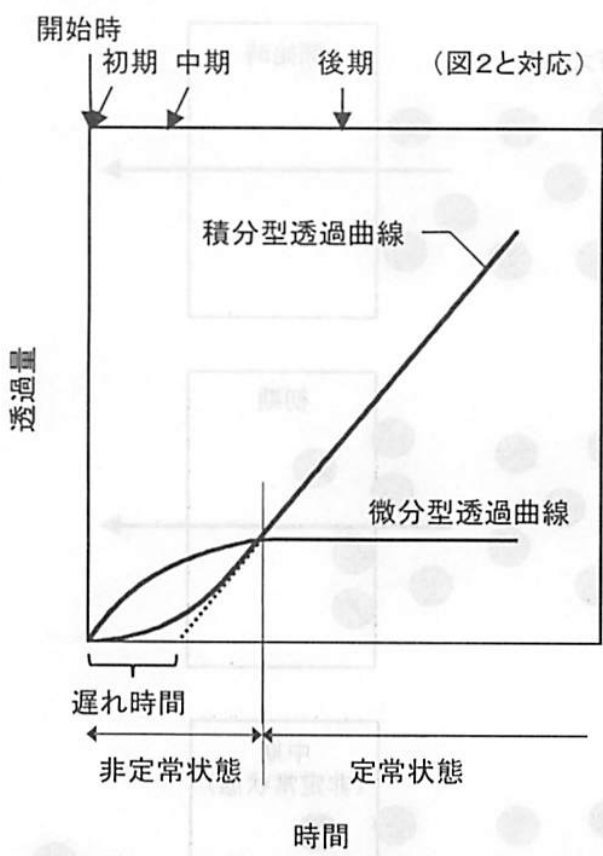

図 3 ガス透過曲線

す。

ある瞬間のガスの透過量を測定した微分型透過曲線とそ の透過量を累積した積分型透過曲線の 2 種類がある。単位 時間当たりの透過量が一定になるまでの状態を非定常状態, そして一定になった状態を定常状態と言う。一般にガスバ リア性は, 定常状態に至ってからの測定データを用いて評 価する。

バリア性が高くなると単位時間あたりの透過量の変位が 小さいため, 定常状態に達する前に誤って測定を終えてし まう場合があるので注意が必要である。その場合, 非定常 状態のデータを使用するので，見掛け上高いバリア值を得 ることになる。食品包装用フィルムの測定は 1 日で行える が, 有機 EL 基板レベルのバリア度では 2,3 週間必要で ある。

ガスバリア性は, 測定方法に依存せずに同一の単位で評 価される。面積 $\mathrm{A}$ のフィムを通しての単位時間あたり のガス透過量 Q を，ガスの透過流束 J (Flux) という。単 位は, 物質量 /(フィルム面積 $\times$ 時間) を示す $\mathrm{mol} \mathrm{m}^{-2} \mathrm{~s}^{-1}$, $\mathrm{cm}^{3} \mathrm{~cm}^{-2} \mathrm{~s}^{-1}, \mathrm{~g} \mathrm{~m}^{-2}$ day ${ }^{-1}$ 等が使用されている。特に水 蒸気や有機蒸気の場合，透過量としてグラム等の質量を用 いる場合が多い。また水蒸気の場合, 透過流束を水蒸気透 過度 WVTR と呼ぶ場合もある。

$$
J=\frac{Q}{A}
$$

フィルムの評価では, 透過流束 $J$ を単位圧力差 $\mathrm{p}_{1}-\mathrm{p}_{2}$ あたりのガス透過量に換算したガス透過度 GTR が用いら れる。ここで $\mathrm{p}_{1}$ と $\mathrm{p}_{2}$ は，それぞれ供給側と透過側のガス の圧力である。

$$
G T R=\frac{J}{p_{1}-p_{2}}=\frac{Q}{A\left(p_{1}-p_{2}\right)}
$$

これは, 透過速度, 透過率と屯いわれる。英語では, Pressure normalized flux, Permeation rate, Permeance, Gas transmission rate (GTR) と表現されている。酸素 ガスの場合, 特に Oxygen transmission rate $\left(\mathrm{O}_{2} \mathrm{GTR}\right.$ やOTR)と言われることあある。

透過度という用語が用いられているが, 上述した水蒸気 透過度 WVTR では圧力差（分圧差）の項が含まれていな い点を注意する必要がある。用語とともに評価值の単位を 確認することを勧める。

ガス透過度 GTR は，フィルムの厚みが不明であっても 測定できる実用的な值である。均質材とともに傾斜材や複 合材にも適用できる。単位は, 物質量/(フィルム面積 $\times$ 時間 $\times$ 分圧差）を示す $\mathrm{mol} \mathrm{m}^{-2} \mathrm{~s}^{-1} \mathrm{~Pa}^{-1}, \mathrm{~cm}^{3} \mathrm{~m}^{-2} 24 \mathrm{~h}^{-1}$ $\mathrm{atm}^{-1}, \mathrm{~cm}^{3} \mathrm{~cm}^{-2} \mathrm{~s}^{-1} \mathrm{cmHg}^{-1}$ 等が使用されている。

また実験サンプルが均質なプラスチックフィルムである 場合, 透過度 GTRにフィルムの厚さ $\ell$ を換算したガス透 過係数 P で評価されている。特に，プラスチック素材同 士の透過物性値の比較に利用されている。これは, ガス 透過率ともいわれ，英語では Permeability coefficient や Permeability と表現されている。日本語では, 式 (2) と 同じ用語が用いられる場合もあるため，前述したように評 価值の単位を確認する等の注意が必要である。この時, 透 過量を $0{ }^{\circ} \mathrm{C}, 1$ 気圧の標準状態 (STP) に換算した值が用 いられる。

$$
P=\operatorname{GTR}(S T P) \cdot \ell
$$

専門業種により異なる単位が使用されているが，未だに SI 単位への移行が進まず，古くから用いられてきた実用 的な単位がそのまま使用されている。

\section{3. ガスバリア性の測定方法の分類と規格}

ガス透過量の主な測定方法の分類を図 4 にまとめる11。 测定方法は, 差圧法と等圧法の 2 つに大別される。それぞ れ，フィルムを挟んで両面のガスの全圧が異なる場合と同

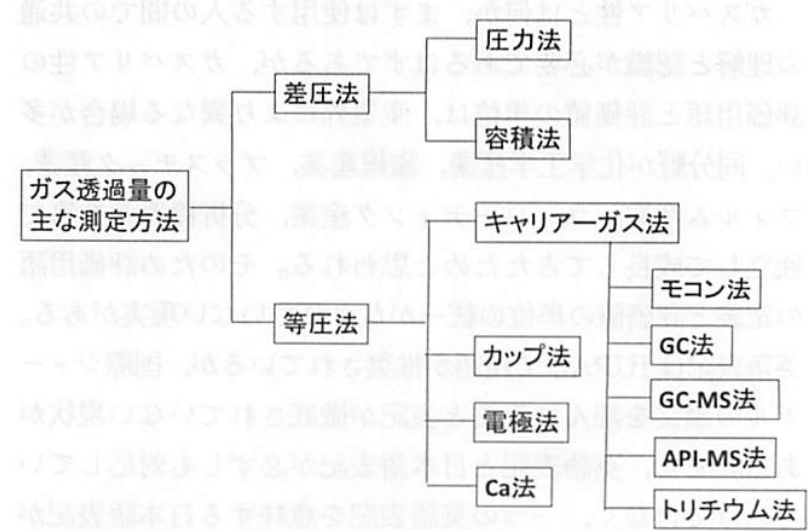

図 4 ガス透過量測定方法の分類 
表 1 ガス透過量測定方法の規格一覧 $\mathrm{a}$

\begin{tabular}{|c|c|c|c|c|c|c|}
\hline \multirow[t]{2}{*}{ 透過物 } & \multicolumn{3}{|c|}{ 差圧法－圧力法 } & \multicolumn{3}{|c|}{ 等圧法 } \\
\hline & JIS & ASTM & ISO & JIS & ASTM & ISO \\
\hline ガス & $\begin{array}{l}\text { K7126-1 } \\
\text { (K7126A) } \\
\text { (Z1707) }\end{array}$ & $\begin{array}{l}\text { D1434M } \\
\text { D1434V }\end{array}$ & $\begin{array}{l}15105-1 \\
(2556)\end{array}$ & $\begin{array}{l}\text { K7126-2 } \\
\text { (K7126B) }\end{array}$ & D3985 & $15105-2$ \\
\hline $\begin{array}{l}\text { 水蒸気 } \\
\text { 限定 }\end{array}$ & K7129C & & $15106-4$ & $\begin{array}{l}\text { K7129A } \\
\text { K7129B } \\
\text { Z0208 }\end{array}$ & \begin{tabular}{|l|} 
F1249 \\
E96 \\
F372
\end{tabular} & \begin{tabular}{|l|}
$15106-1$ \\
$15106-2$ \\
$15106-3$ \\
2528
\end{tabular} \\
\hline
\end{tabular}

a）カッコ内は改正前の規格番号

b) 容積法

じ場合である。両法の原理に基づいて制定されている規格 を表 1 に示す。技術の進歩に伴い, 替格の改廃や制定が行 われてきている。表 1 には, 改正前の規格番号もカッコ内 に示している。

例えば, JIS K7126の解説によると, 同規格が食品用 包装フィルムのガスバリア性評価を念頭において制定され たことがわかる。しかし，その他の用途のフィルムむ同様 の原理に基づいて評価することができる。既存の規格は, フィルムのガス透過量測定法において, 限定された評価方 法である。図 4 で分類されている方法は, 必ずしあ表 1 の 各種規格により認定されているものばかりではないが, 学 術分野や各企業で, 様々なガスに対して幅広く応用されて いる。近年のセンサーの精度や測定の自動化等の技術の進 歩は目覚しいむのである。JIS, ASTM そして ISO で制 定された規格でも，その本質的な内容を順守しつつ, 最新 の技術を用いて実験を行うのが好ましいと考える。

そもそあ規格とは何かについて，同分野を例にして述べ ておく。バリア性を高めるための研究開発において, フィ ルムの化学構造や形態とガス透過性との関係を把握する必 要がある。ガス透過性の中であ水蒸気透過性の挙動は複雑 である。実際に市販されるフィルムは, プラスチックが主 成分であるが，様々な有機物質や無機物質の添加物が加え られている。その結果, フィルムに対する水蒸気の収脱着 や拡散挙動には相対湿度依存性がある上に, 個々のフィル ムの両挙動が複雑に絡み合うため, 一般に水蒸気透過度は 測定方法や測定条件により值が異なる。

一方, 製品の品質保証においては, 製造会社の社内基準 だけでなく商取引に係わる人々が共通で良し悪しを判断す るデー夕が求められる。従って, 限定された条件の測定值 を基に判断する基準，すなわち規格が必要となる。表 1 の 規格は試験方法であるため, 測定方法毎に温度と湿度が 規定されている。食品用包装フィルムでは保存可能期間 (shelf life) の計算のために水蒸気透過度のデータが必要 となるため, 温度と湿度の組み合わせはこれを基としてい る。一般的な室内での温湿度を $25^{\circ} \mathrm{C}, 60 \% \mathrm{RH}$ 付近とし， 流通先の高温多湿な保存環境として $40^{\circ} \mathrm{C}, 90 \% \mathrm{RH}$ まで
の範囲を規定し，フィルムのバリア性を水蒸気透過度から 評価している。そのため，電子デバイス製品用途の判断に この条件を当てはめて良いかどうかは議論が必要となる。

\section{4. 差圧法によるガスバリア性の測定評価}

差圧法におけるフィルムを通してのガス透過の駆動力は 圧力差である。フィルムの片面からガスを供給する。その 反対側は，常に供給したガスの圧力よりあ低い圧力に保た れている。差圧法は, 圧力法と容積法の 2 つに分類できる。 圧力法の内，透過側を真空にしている場合を特に，加圧真 空法という。容積法は, 体積法や体積変化法とよばれる場 合もある。

フィルムを透過したガスの量は，単位時間当たりに透過 したガスの体積としてフローメーターで測定できる（容積 法）(ASTMD1434V)。また別な方法として，透過側の容 積を密封しておき, ガスの透過に伴うこの容積内の圧力増 加を圧力センサーで読み取り，この際の単位時間あたりの 圧力増加を透過量に变換する方法（圧力法）む広く利用さ れている（ISO15105-1, ASTMD1434M, JIS K7126-1 附属書 1)。規格の主流は, 圧力法である。混合ガスの測 定では，透過したガス成分の同定に，ガスクロマトグラフ （GC）(JIS K7126-1 附属書 2, JIS K7129 C, ISO15106 -4) や質量分析器 (GC-MS) が用いられている。

圧力法は，高透過性からハイバリア性（低透過性）の材 料まで幅広く評価することができる。容積法は，高透過性 材料の評価に適するが，バリア性の評価に難がある。ガス バリア性が高いフィルムのガス透過量は極端に少ないため, フローメーターでの透過量の検出が困難だからである。規 格の主流は压力法であるが，これは上述したように包装用 バリアフィルムの評価を念頭においたすのだからである。

\section{5. 等圧法によるガスバリア性の測定評価}

等圧法では, フィルムの両面のガスの全圧は同じである。 そのため, フィルムを通してのガスの透過の駆動力として, ガス濃度差 (分圧差) を利用する。一般に全圧は 1 気圧に 設定して実験することが多い。フィルムの片面からガスを 
供給して，その反対側にはキャリアーガスを流しておくキャ リアーガス法が一般的である。この透過したガスの量は， 酸素電解センサー（クーロメトリック）（ISO15105-2, ASTM D3985, JIS K7126-2 附属書 A), ガスクロマト グラフ (GC) (JIS K7126-2 附属書 B), 水蒸気赤外セ ンサー (ASTM F1249, ASTM F372, JIS K7129 B, ISO15106-2), 感湿センサー (JIS K7129 A, ISO151061), 五酸化二リンセンサー法 (ISO15106-3), 質量分析器 GC-MS や大気圧イオン化質量分析装置 API-MS 等のセ ンサーを用いて検出する。クーロメトリック法, 水蒸気赤 外センサー法と五酸化二リンセンサー法は, 米国 Mocon （モコン）社の透過量測定装置の測定原理であることから, この方式の等圧法を, 特にモコン法と呼ぶ場合むある。ま た，キャリアーガスを用いるが純水の水蒸気のかわりにト リチウムをトレーサーとして用いるトリチウム法むある。 一般的に，キャリアーガス法とひとくくりせずに，代表的 な検出器の名前で呼ばれる場合が多い。

水蒸気透過度測定の原点はカップ法 (JIS Z0208, ASTM E96）である。カップに無水塩化カルシウムを入れ，測定 するフィルムでカップに封をする。フィルムを透過した水 蒸気をカップ内の塩化カルシウムが吸湿する。この際の塩 化カルシウムの重量増加から水蒸気透過量を決定する方法 である。これをドライカップ法という。あらかじめ水をカッ プに入れフィルムでカップに封をした後，透湿による水の 重量減少を測定する方法むある。これはウエットカップ法 と呼ばれている。水蒸気透過度は, カップの質量を天秤で グラム単位で何日もかけて測定していたことから 1 日あた りの重量増加をあらわす $\mathrm{g} \mathrm{m}^{-2} \mathrm{day}^{-1}$ が単位として使用 され始め, 現在にまで通じている。上述した種々のセンサー を用いた測定においても，わざわざ透過量をグラムに変換 している。また，温湿度を一定とした条件での等圧法での 測定のため, 分圧差の項は加えられていない。ちなみに酸 素等のガスは流量計を用いた差圧法で測定され出したため, 透過量は体積を表す $\mathrm{cm}^{3} \mathrm{~cm}^{-2} \mathrm{~s}^{-1} \mathrm{cmHg}^{-1}$ が使用されて いた。水蒸気透過量も差圧法で測定した場合は, その単位 として圧力項が入った $\mathrm{cm}^{3} \mathrm{~cm}^{-2} \mathrm{~s}^{-1} \mathrm{cmHg}^{-1}$ が使用され ている。

等圧法は差圧法と比較して, 装置内に湿気が存在する条 件下においても測定が容易である。つまり相対湿度の異な る環境下におかれたフィルムの酸素等のガス透過性を評価 することができる。また, フィルムが水と接している場合 のガス透過性の評価には, 電極法が用いられる。ガス検出 用電極の先にフィルムを固定化し水中に浸漬させて, 酸素 等の溶存ガスの透過量を測定する。

カルシウム腐食法 (Ca 法) は, 金属カルシウムが水分 子と反応して無色の水酸化カルシウムへと変化することを 利用した測定方法である。この検出方法には，透明スポッ
ト部のサイズや数から透過度を算出する腐食スポット方式, 光線透過率や光学密度の変化を検出する光学特性方式, 電 気抵抗の变化を測定する電気特性方式の 3 種類がある。 $\mathrm{Ca}$ 法の大きな利点は, カップ法と同様に，感湿センサー としての機能を持つカルシウムを組み込んだセル構成となっ ているために, 他の機器測定方法と異なり測定装置を一つ のサンプルが長期にわたって占有する必要が無いことにあ る。測定サンプルは恒温恒湿下に保管し, 測定時に取り出 して測定する形式であれば，同時に複数のサンプルについ て評価を行うことが可能である。

\section{6. ハイパリア性評価の現状と課題}

上述した様に，ガスバリア性評価のために様々な測定評 価方法が考案されてきている。しかしながらフレキシブル エレクトロニクスデバイス分野で要求されるハイバリアフィ ルムのガスバリア性評価ができる標準規格はなく，測定精 度の保証のために必要な標準試料む存在しない状況である。 この分野では, 求められるバリア性は，ほとんどが水蒸気 に対してである。

水蒸気透過度 $10^{-3} \mathrm{~g} \mathrm{~m}^{-2}$ day $^{-1}$ を超えるハイバリア性 は, 学術文献等からは, $\mathrm{Ca}$ 法で透過度を求めている場合 が多い。Ca 法には，金属カルシウムの蒸着条件，蒸着層 の金属カルシウムの密度，水分子と金属カルシウムとの膜 厚方向への反応率等の仮定条件の妥当性, 検出器の精度, フィルムの前処理条件, 校正法, 封止材のバリア度等の学 術文献では詳細に記載されない事項に測定精度のカギがあ る。例えば，フィルム基板の代わりにガラス基板を用い た場合，理想的には完全なバリア性を示すはずであるが， リークが認められている報告がある2)。これは主に封止材 の封止性に依存していることを示しており， Ca 法の測定 限界に関連する重要な因子である。この封止材のバリア性 評価も研究課題となっている。

水蒸気透過度の測定に際し,フィルム基板内部や表面に 元々収着していた水分子や, 配管内部に吸着していた水分 子の脱離を誤って測定値として見てしまう場合あある。八 イバリア性評価においては「その水分子はどこから来たも のなのか」を意識しながら実験を行う必要がある。

均質なプラスチックフィルムの水蒸気透過性は, 温度と 湿度に影響を受け，一般に相対湿度が高くなるほど透過度 は増加する。つまり異なる温湿度条件で測定された水蒸気 透過度を比較するのは難しいということである。そのため JIS 規格や ISO 規格では，温湿度条件を規定している。

前述した様にハイバリアフィルムでは，プラスチックフィ ルム上に無機薄膜層が形成され，さらにバウムクーヘン状 に積層されている。無機薄膜層に欠損部位が無ければ完全 なバリア性が得られるはずであるが実際はそうではない。 天井からの雨漏りの様に, 水分子は, 無機薄膜層の欠損部 
分を選択的に透過すると考えられる。この挙動は, Ca 法 腐食スポット方式で観察することができる。

水分子の透過は, 均質なプラスチックフィルムに対する 溶解拡散機構と異なり, 無機薄膜層の欠損部分は, その孔 径や経路, 曲路率により, クヌーセン流れやポアズイユ流 れ等が起こると考えられる。また, 一般に無機薄膜素材と して使用されている金属酸化膜は水と強い相互作用を示す。 そのため温度と湿度の透過度依存性はより複雑となる。酸 素透過度を絶対温度の逆数に対してプロットすると, 多く の場合, 直線関係を示すため, アレニウス式から活性化エ ネルギーを算出して透過度の予測に利用されている。しか しながら水蒸気透過度に関しては, 必ずしも直線関係を示 すとは限らないのである。

参考までに, クヌーセン流れとポアズイユ流れについて の説明を加えておく。フィルムに直径 $50 \AA \sim 1 \mu \mathrm{m}$ 程の円 筒型の貫通孔が空いていたとする。この孔の中をガス分子 が移動する時, 別のガス分子に衝突する距離である平均自 由行程を $\lambda$, 孔の半径を $\mathrm{r}$ とすると, $\mathrm{r} / \lambda$ がガスの流れ を決める。 $\mathrm{r} / \lambda>5$ の時, ガス透過速度はガスの粘性の逆 数に比例するポアズイユ流れ (Poiseille flow) を示す。 $\mathrm{r} / \lambda$ が小さくなるにつれ，孔の中でガス分子同士が衝突 するよりも，ガス分子は孔の壁に衝突する割合が多くなる。 そして $\mathrm{r} / \lambda<1$ の時, ガス透過速度はガスの分子量の平 方根の逆数に比例するクヌーセン流れ (Knudsen flow) を示すようになる。

次世代のハイバリア性評価に関して求められる測定評価 条件としては, 有機 EL 基板で求められる $10^{-6} \mathrm{~g} \mathrm{~m}^{-2} \mathrm{day}^{-1}$ レベルの高感度測定を短時間で行えることはもちろんだが, バリア性能が上がるとそれに応じて長くなる測定時間への 対応も必要である。測定装置を一つのサンプルが長時間占 有するようなタイプの測定法は, 工業的な品質保証用途ま で考えると望ましいとは言えない。測定装置を占有しない ためには, 複数のサンプルを並行して評価出来ることが要
請され，この点を解決するためには測定セルが独立してい る形式の測定法が望ましい。また, 測定精度の保証のため には，標準試料が必要である。

\section{7. おわりに}

バリア性評価と言っても多くの測定方法がある。実際に 得たいバリア性のデータと評価方法が一致しているかどう かとともに, 検出器で検出したガスが本当に測定フィルム を透過してきたものなのかどうかをよく検証しながら実験 を行う必要がある。上述した様に有機 EL 基板に求められ るレベルのハイバリア性評価のための標準規格はなく, 測定精度の保証のために基準として必要な標準フィルムむ 存在しない状況である。電子デバイス部材の研究開発の 促進のために, 一日も早い ISO 国際標準化が求められて いる。

参考図書として「バリア技術（共立出版, ISBN978-4320-04447-0)」，「最新バリア技術〜バリアフィルム，バ リア容器, 封止材・シーリング材の現状と展開〜（シーエ ムシー出版, ISBN978-4-7813-0507-3)」,「高分子膜を 用いた環境技術（共立出版, ISBN 978-4-320-04430-2)」 を薦める。バリアは裹方の技術だが, 幅広い分野で必要と されていることがわかる。

また，本報で記載した国内外の規格は，日本国内では一 般財団法人日本規格協会がライセンスを有しているので, 同協会のホームページ (http://www.jsa.or.jp/default.asp) から入手することができる。

\section{文献}

1）永井一清監修, “気体分離膜・透過膜・バリア膜の最新技術”, シーエムシー出版, 東京 (2007).

2) A. G. Erlat, M. Schaepkens, T. W. Kim, C. M. Heller, M. Yan, and P. McConnelee, $47^{\text {th }}$ Annual Technical Conference Proceedings, Society of Vacuum Coaters, p. 654 (2004). 